\title{
In vitro growth response to bacterial wilt pathogen of banana (var. lakatan, Musa acuminata Colla) plantlets regenerated from ethyl methanesulfonate-treated shoot explants
}

\author{
Nonna Fatima H. Abello' and Tessie C. Nuñez ${ }^{2 *}$
}

\begin{abstract}
Bacterial wilt caused by Ralstonia solanacearum leads to death of infected suckers and reduces the yield of commercially important banana varieties like Lakatan. Among the many varieties of banana, no germplasm with bacterial wilt resistance has been identified yet (Tripathi et al 2004).

Mutation induction in plants to develop disease resistance genes using physical or chemical mutagens has been used as alternative to harmful pesticides. To induce mutation for the possible development of resistance to bacterial wilt, shoot tips of Stage 2 in vitro-grown Lakatan plantlets were exposed to $0.1 \%$ and $0.2 \%$ ethyl methanesulfonate (EMS) for 12 and $24 \mathrm{~h}$. Treated and untreated explants were cultured in vitro to regenerate plantlets.

Shoots emerged two days after in vitro inoculation of explants treated with $0.1 \%$ EMS for $12 \mathrm{~h}$. Significantly longer shoots also developed from the cultures compared to the untreated explants. The other explants exposed to other treatments had shoot emergence one to three days later. Falcate, curled, irregularlyshaped, and yellowish leaves and pseudostems also developed in EMS-treated cultures.

Untreated plantlets exhibited at least one bacterial wilt symptom such as leaf spots, necrosis at pseudostem base, and death six days from the introduction of Ralstonia solanacearum in vitro. Plantlets from explants exposed to $0.1 \%$ EMS for $12 \mathrm{~h}$ did not exhibit disease symptoms even after ten days of exposure to the pathogen and had $100 \%$ survival. Seventy one percent of plantlets from explants exposed to $0.1 \%$ EMS for $24 \mathrm{~h}$ and $55 \%$ from explants treated with $0.2 \%$ EMS for $24 \mathrm{~h}$ also survived without infection. The surviving plantlets need to be studied further for their ex vitro responses to the pathogen and determine possible genetic changes due to the chemical mutagen treatment.
\end{abstract}

Keywords: in vitro growth of banana, Ethyl methanesulfonate, Bacterial wilt screening, Ralstonia solanacearum

'Department of Biotechnology, Visayas State University, Visca, Baybay City, Leyte, Philippines 6521, and Center for Studies in Biotechnology, Cebu Technological University

${ }^{2}$ National Coconut Research Center-Visayas,Visayas State University

*Corresponding Author. Address: National Coconut Research Center-Visayas,Visayas State University; Email:tessie.nunez@vsu.edu.ph 
In vitro growth response to bacterial wilt pathogen of banana

\section{INTRODUCTION}

Banana (Musa sp.) is the largest agricultural commodity of the Philippines (PSA 2016). The three major banana cultivars in the country are the Cavendish, Saba, and Lakatan. Lakatan (Musa acuminata Colla) is the fifth most important banana crop in world trade. This variety can lower blood pressure because of its high potassium and low salt contents (Dadang 2014). However, Lakatan production in the Philippines is severely affected by many disease-causing bacteria such as the bacterial wilt organism Ralstonia solanacearum. Since no banana germplasm has the gene for resistance to the disease (Tripathi et al 2004), an alternative solution to the use of pesticides is to develop resistance genes by inducing mutation through the use of chemical mutagens like Ethyl methanesulfonate (EMS). Chemicallyinduced mutant genes have been developed for resistance to the Fusarium oxysporum f. sp. Cubense in Brazil banana, and Pseudomonas syringae in tomato. EMS is a very effective mutagen for creating somaclonal variations in banana (Omar et al 1989). Hence, it was used in this study for the possible induction of genetic changes that may lead to the development of resistance to bacterial wilt in tissue-cultured shoots of Lakatan.

\section{MATERIALS AND METHODS}

\section{Preparation of Explants and Treatment with EMS}

The study was done in factorial set up in Complete Randomized Design with three replicates, five samples per treatment per replicate. Stage 2 Lakatan shoots (Figure 1) were obtained from the Experiment Station Laboratory of the Department of Agriculture in Balinsasayao, Abuyog, Leyte. Shoots were soaked in either sterile $0.1 \%$ EMS, $0.2 \%$ EMS, or in distilled water (control) for 12 or $24 \mathrm{~h}$ as treatments (Table 1).

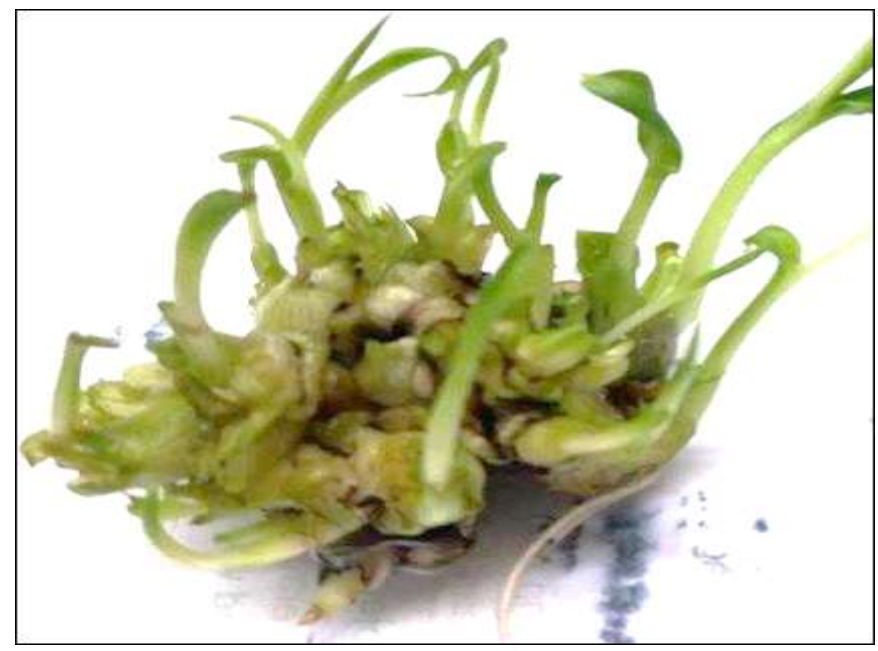

Figure 1. Stage 2 in vitro grown shoots of Lakatan used as source of explants 
Table 1. Treatments for the induction of mutagenesis in Lakatan shoot tip explants of Lakatan

\begin{tabular}{ccc}
\hline Treatment Code & EMS concentration & Duration of exposure $(\mathrm{h})$ \\
\hline T01 & $\begin{array}{c}\text { Distilled water } \\
\text { (No EMS) }\end{array}$ & 12 \\
T02 & & 24 \\
& $0.1 \%$ & 12 \\
T11 & & 24 \\
T12 & & \\
& $0.2 \%$ & 12 \\
T21 & & 24 \\
T22 & & \\
\hline
\end{tabular}

\section{Medium Preparation and Culture of Treated Explants}

Murashige and Skoog (1962) medium with supplements suitable for banana culture was prepared following standard procedures. Fifteen milliliters of the medium was dispensed to each culture vessel. The medium was autoclaved at $121^{\circ} \mathrm{C}$ and $15 \mathrm{psi}$ for $20 \mathrm{mins}$ and cooled for one day before use.

After exposure to treatments, tightly-packed layers of leaf sheaths were removed from the shoots to expose the shoot tip. The actively dividing region was excised aseptically and inoculated individually into each culture vessel. Cultures were incubated at $26 \pm 1^{\circ} \mathrm{C}$ under $8 \mathrm{~h}$ per day lighted condition until plantlets had developed three to four leaves. The explants were observed weekly to monitor growth.

\section{Isolation of Bacterial Wilt Causal Organism from Infected Banana Tissues}

Ralstonia solanacearum was isolated from the glosses of banana fruits exhibiting symptoms of the disease known as "bugtok" in Leyte, Philippines, and cultured at the Plant Disease Diagnostic Laboratory of the Visayas State University. Terazolium Chloride Agar (TCA) medium was used to verify the virulence of the isolated bacteria. Pink bacterial colonies with cream peripheral growth were observed which are characteristic of very virulent bacterial wilt pathogen (Figure 2a $\& 2 b)$.

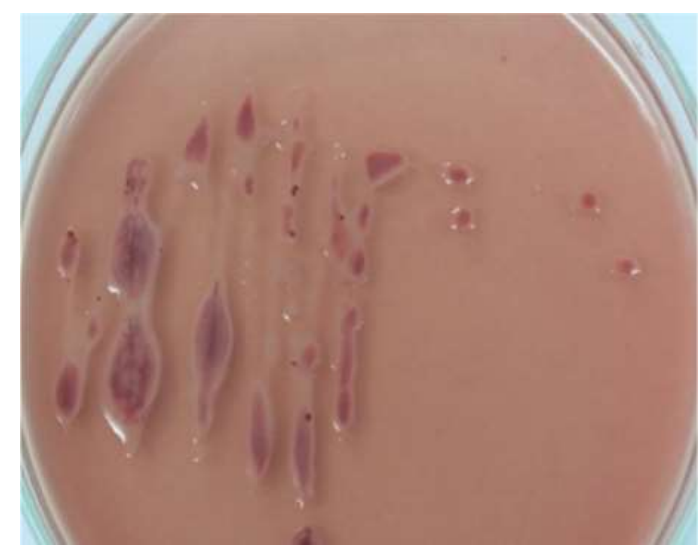

Figure 2a. Colonies of Ralstonia solanacearum in TCA medium 
In vitro growth response to bacterial wilt pathogen of banana

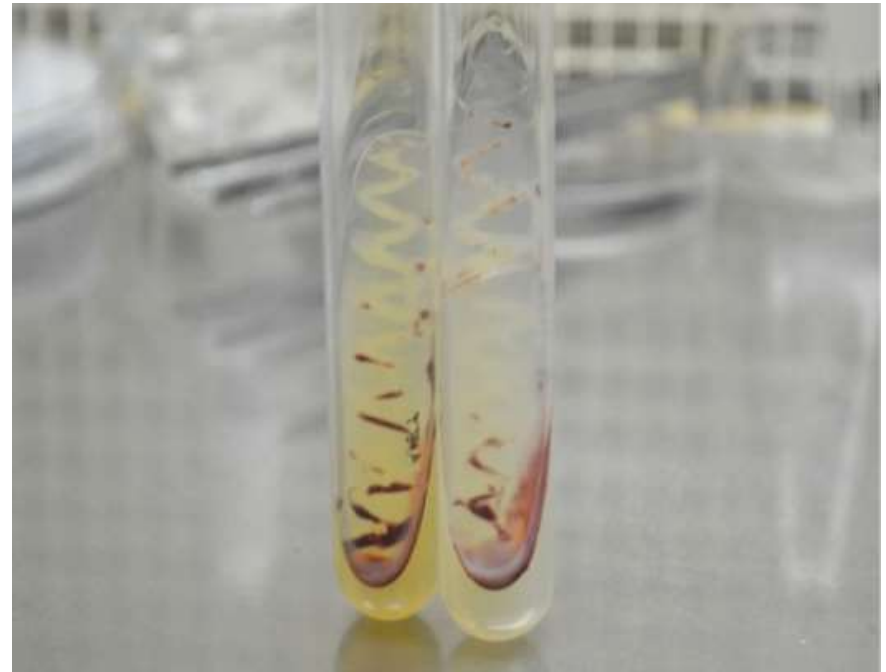

Figure $2 \mathrm{~b}$. Isolated Ralstonia solanacearum used in the preparation of bacterial suspension inoculated into the Lakatan cultures

\section{In vitro Screening for Response to Ralstonia solanacearum}

The bacterial suspension was prepared by adding sterile distilled water to the culture, scraping the bacterial colonies and shaking the solution well. One milliliter of the bacterial suspension was introduced into each culture with the untreated and EMS-treated regenerated plantlets inside a laminar flow hood to avoid contamination. The cultures were observed for symptoms of the bacterial infection for ten days after the introduction of the pathogen.

\section{RESULTS AND DISCUSSION}

\section{Effects of EMS Treatments on the Growth of the Explants}

Ethyl methanesulfonate (EMS) treatments enhanced the development of shoots from the explants, suggesting that $0.1 \%$ and $0.2 \%$ concentrations did not cause damage to the explants. Shoots emerged from the explants treated with $0.1 \%$ EMS for $12 \mathrm{~h}$, two days after inoculation (Figure 3 ). Explants treated with $0.1 \%$ EMS for $24 \mathrm{~h}$ and those treated with $0.2 \%$ EMS for $12 \mathrm{~h}$ developed shoots on the third day. Those exposed to $0.2 \%$ EMS for $24 \mathrm{~h}$ and the untreated explants had shoot emergence four to five days from inoculation. A similar study by Dhakshanamoorthy et al (2010) also showed that the longer the duration of EMS treatment, the longer the time for the explants to grow. Jabeen and Mirza (2004) explained that the growth of shoots is influenced by many genes (polygenic) and higher mutagen concentration might affect at least one of these genes. 
Abello \& Nuñez

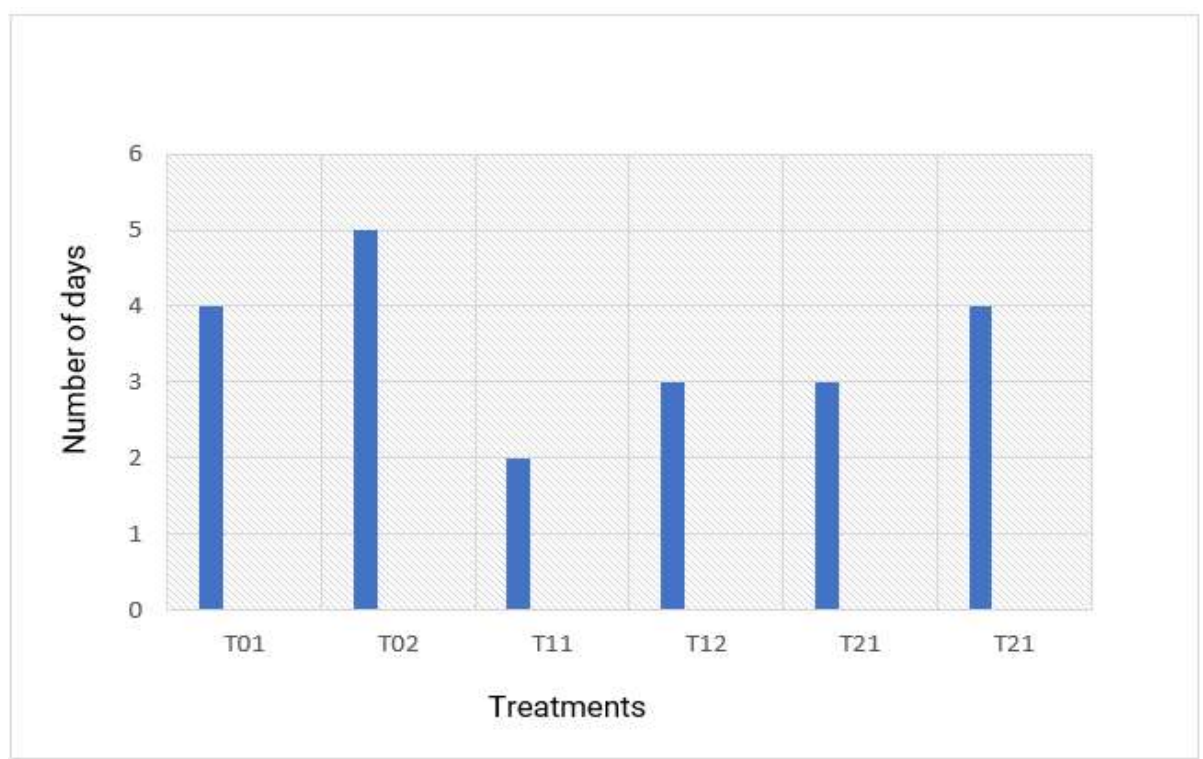

Figure 3. Number of days to shoot emergence from Lakatan explants

Secondary shoots were produced in all explants except in the control which was soaked for $12 \mathrm{~h}$ in water. Some control explants did not even develop the primary shoot (Figure 4). Although the average number of shoots was higher in explants exposed to $0.1 \%$ EMS for $24 \mathrm{~h}$, differences in shoot production among treatments were not significant.

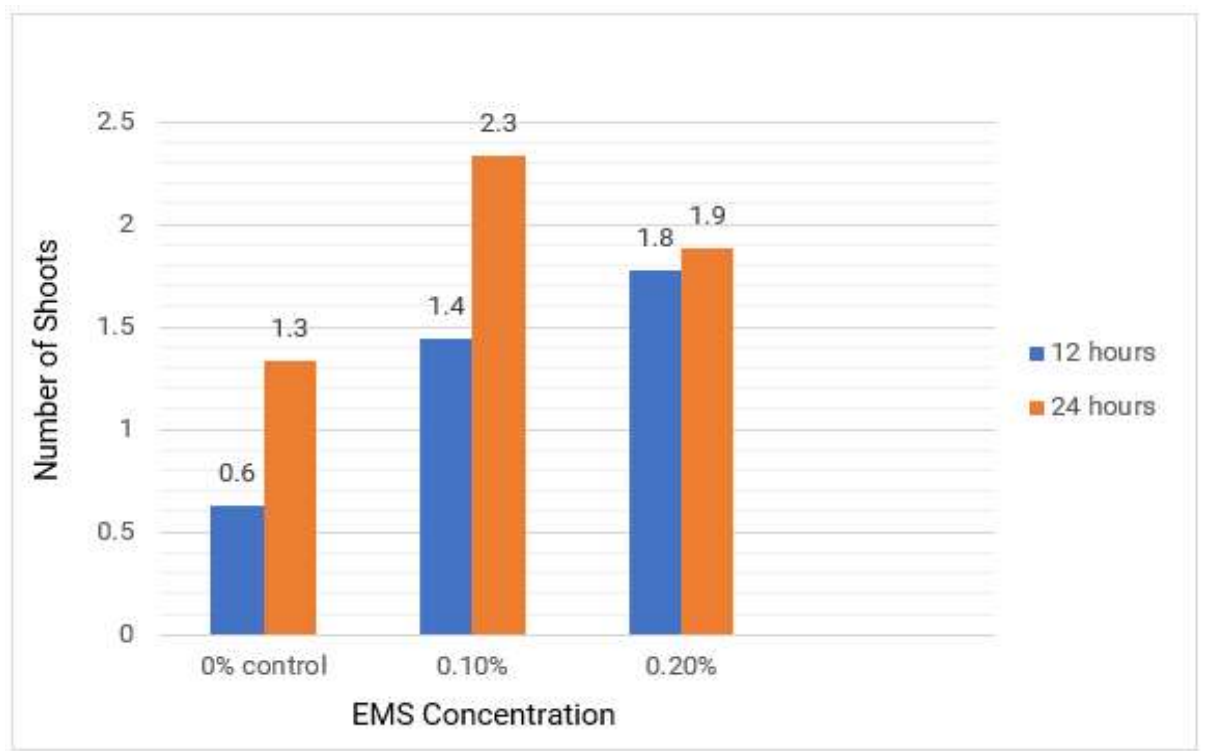

Figure 4. Average number of shoots produced per explant after EMS treatment 
In vitro growth response to bacterial wilt pathogen of banana

EMS treatment significantly improved the growth of shoots. Shoots of EMStreated explants generally grew faster than the control and shoots from explants treated with $0.1 \%$ EMS for $12 \mathrm{~h}$ were significantly longer than the untreated ones (Figure 5). However, at the same concentration of EMS, longer exposure to treatment resulted in shorter shoots. Nevertheless, the negative effect of longer exposure to higher EMS concentration on shoot growth was not significant.

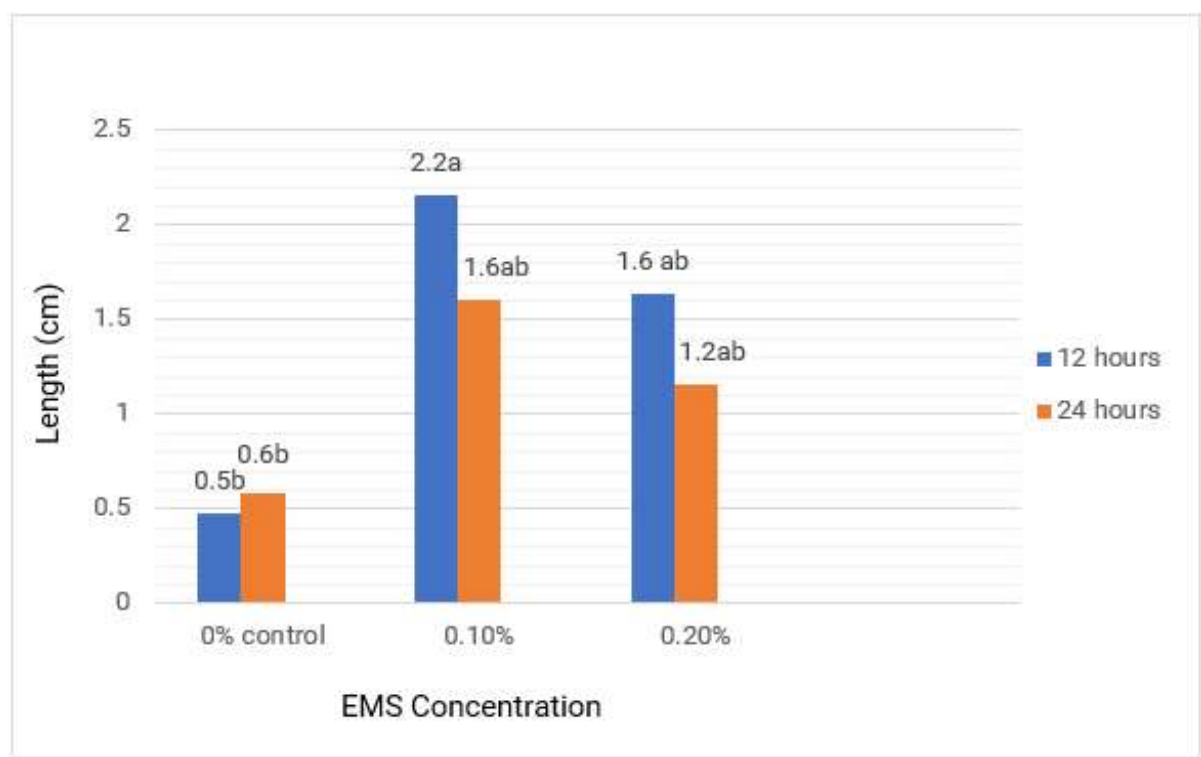

Figure 5. Average length of shoots produced by untreated and EMS-treated explants

The production of the shortest shoots in the control was not in line with most reports on the effects of EMS treatment on plants. A study on mutation induction in sugarcane showed that the untreated plants had longer shoots than the treated ones (Khan 2009). According to Konzak et al (1965), high concentrations of mutagenic agents can cause biological damage like seedling injury, lethality, and sterility, which increases with the increase in dosage and at a faster rate than the mutations. The significant difference in length of shoots between the explants treated with $0.1 \%$ EMS for $12 \mathrm{~h}$ and the control might be due to enhanced production of hormones responsible for growth in the former.

\section{Morphology of Shoots from EMS-Treated and Untreated Explants}

Different colors and shapes of leaves were observed among shoots from different treatments. Untreated shoots had no color change and elliptic and lanceolate leaves were the most common (Table 2, Figures $6 \& 7$ ). Shoots of explants exposed to $0.1 \%$ EMS for $12 \mathrm{~h}$ had yellowish pseudostem with leaf shape similar to the control, while those from explants treated with the same concentration for $24 \mathrm{~h}$ developed curled and falcate leaves, in addition to yellowish pseudostem. Shoots from cultures exposed to $0.2 \%$ EMS for $12 \mathrm{~h}$ were distinctly yellow including the leaf margins but the shape was similar to those developed in 
explants treated with lower EMS concentration. Exposure to $0.2 \%$ EMS for $24 \mathrm{~h}$ caused the development of falcate and irregularly-shaped leaves in entirely yellowish shoots. Color changes are common in mutant plants.

Table 2. Morphology of shoots from EMS-treated and untreated explants of Lakatan

\begin{tabular}{ccc}
\hline Treatment & Color & Leaf Shape \\
\hline $\mathrm{T}_{01}: \mathrm{no}$ EMS, 12h & Green & Elliptic \\
$\mathrm{T}_{02}:$ no EMS, 24h & Green & Lanceolate \\
$\mathrm{T}_{11}: 0.1 \% \mathrm{EMS}, 12 \mathrm{~h}$ & Yellowish & Elliptic \\
$\mathrm{T}_{12}: 0.1 \% \mathrm{EMS}, 24 \mathrm{~h}$ & Yellowish pseudostem & Curled Elliptic, Falcate \\
$\mathrm{T}_{21}: 0.2 \% \mathrm{EMS}, 12 \mathrm{~h}$ & Yellow including the leaf margins & Elliptic, Lanceolate \\
$\mathrm{T}_{22}: 0.2 \% \mathrm{EMS}, 24 \mathrm{~h}$ & Yellow entirely & Lanceolate, Elliptic, \\
& & Falcate, Irregular \\
\hline
\end{tabular}

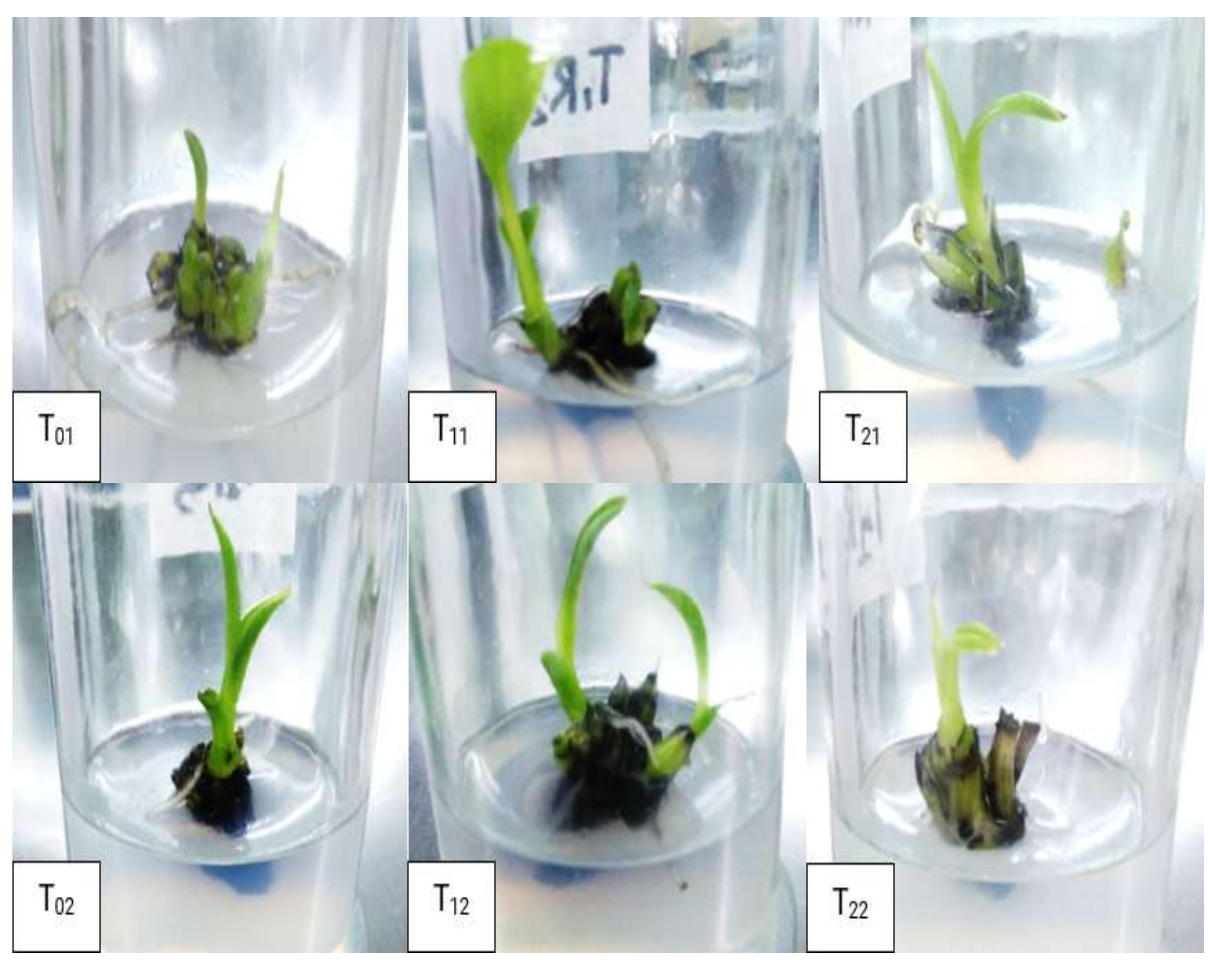

Figure 6. Colors of Lakatan shoots as affected by EMS treatment 
In vitro growth response to bacterial wilt pathogen of banana

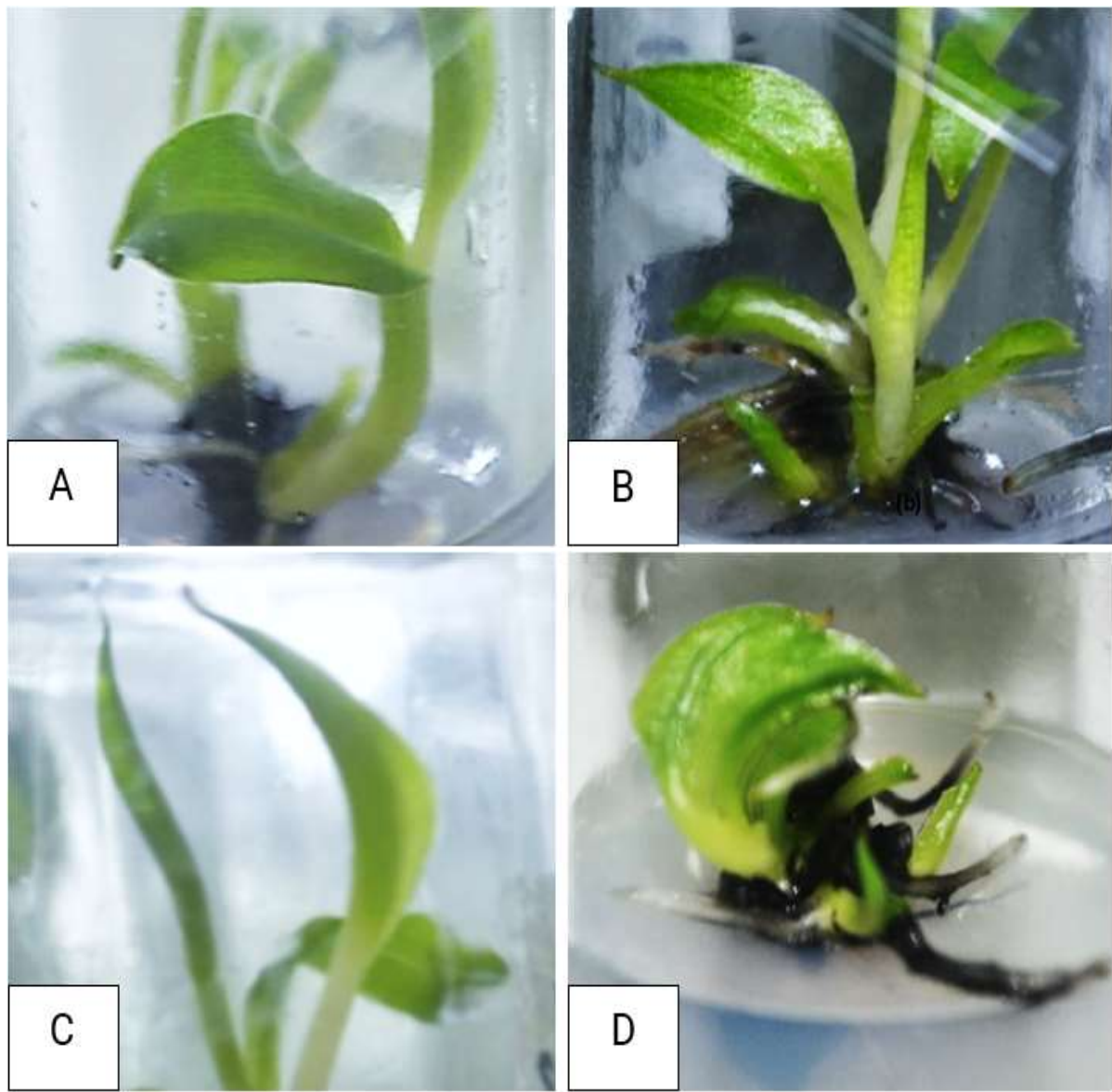

Figure 7. Leaf shapes of Lakatan shoots as affected by EMS treatment: (a) elliptic, (b) lanceolate, (c) falcate, and (d) curled/irregular

Response of Regenerated Shoots from Untreated and EMS-treated Explants to Ralstonia solanacearum

Bacterial colonies formed at the roots of cultures one day after inoculation. However, no bacterial wilt symptoms were observed on the shoots (Figure 8). As reported by Alvarez et al (2006), the bacteria can enter through physical wounds or natural openings, and attach at two precise root sites: the root elongation zones and axils of emerging or developed lateral roots. The root cortex of these zones may have the intercellular spaces invaded and filled with bacteria. 


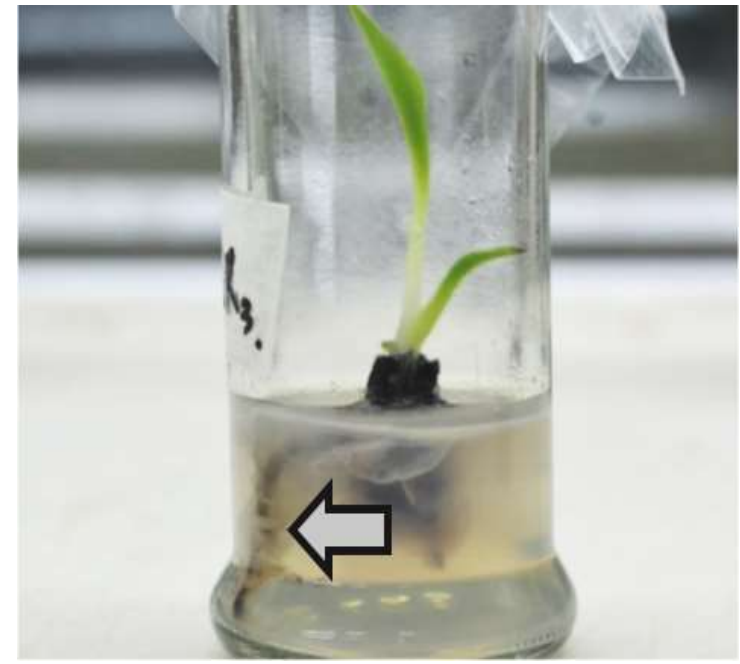

Figure 8. Formation of colonies of Ralstonia solanacearum in roots of an in vitro-grown Lakatan plantlet

Different bacterial wilt symptoms such as black and brown leaf spots, softening of tissues of the plants and death of plants were observed (Figure 9). Leaf spot was the most common. The control plants developed severe leaf spots while some EMS-treated plantlets had leaf spots which were not as severe as those in the control plantlets. Symptoms were first observed in the control plants six days after introduction of the pathogen (Table 3). Ten days after inoculation of the pathogen, disease symptoms also developed in some EMS-treated plants but the plantlets from explants treated with $0.1 \%$ EMS for $12 \mathrm{~h}$ (T11) had no observable symptoms.
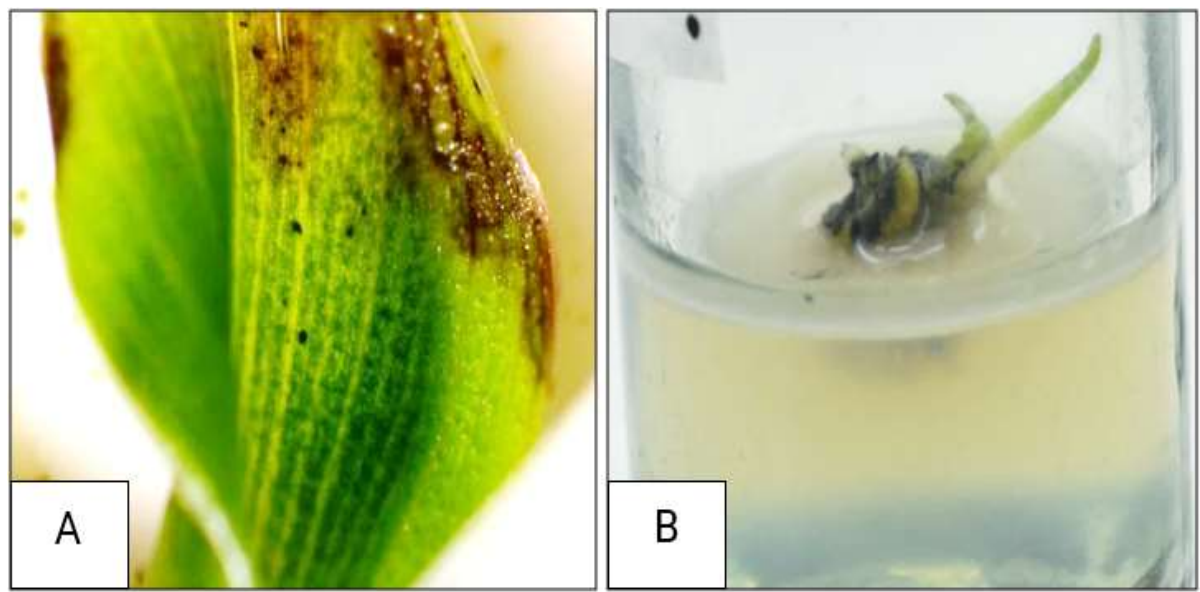

Figure 9. Bacterial wilt symptoms in in vitro-grown plantlets: (a) leaf spots in untreated plantlets, (b) softening of tissues resulting in slumping of the plantlets and (c) dead plantlets 
In vitro growth response to bacterial wilt pathogen of banana

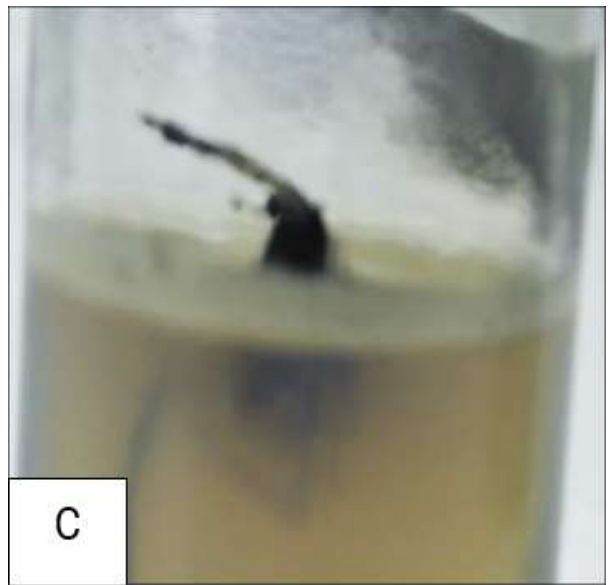

Figure 9. Continuation Bacterial wilt symptoms in in vitro-grown plantlets: (a) leaf spots in untreated plantlets, (b) softening of tissues resulting in slumping of the plantlets and (c) dead plantlets

Table 3. Duration from pathogen introduction to the first appearance of bacterial wilt symptoms

\begin{tabular}{cc}
\hline Treatment & Duration (days) \\
\hline $\mathrm{T}_{01}$ & 6 \\
$\mathrm{~T}_{02}$ & 6 \\
$\mathrm{~T}_{11}$ & no symptoms \\
$\mathrm{T}_{12}$ & 10 \\
$\mathrm{~T}_{21}$ & 10 \\
$\mathrm{~T}_{22}$ & 10 \\
\hline
\end{tabular}

Dissected plantlets from the control explants $\left(T_{01} \& T_{02}\right)$ also showed necrosis at the base of the pseusodostems (Figure 10). All $\mathrm{T}_{11}$ plantlets had clean pseudostem bases. Although some $T_{12}$ plantlets had leaf spots, their pseudostems were clean. Plantlets from explants treated with $0.2 \%$ EMS for $12 \mathrm{~h}\left(T_{21}\right)$ had clean pseudostem bases but leaf spots were observed in lesser degree than those found in the control plantlets. Among explants exposed to $0.2 \%$ EMS for $24 \mathrm{~h}\left(\mathrm{~T}_{22}\right)$, pseudostem rot was observed in some plantlets with leaf spots. These observations were similar to the study of Bhagwat and Duncan (1988) and of Saraswathi et al (2014) on mutation induction in banana for the development of genes against Fusarium oxysporum and Black Sigatoka, respectively. 
Abello \& Nuñez
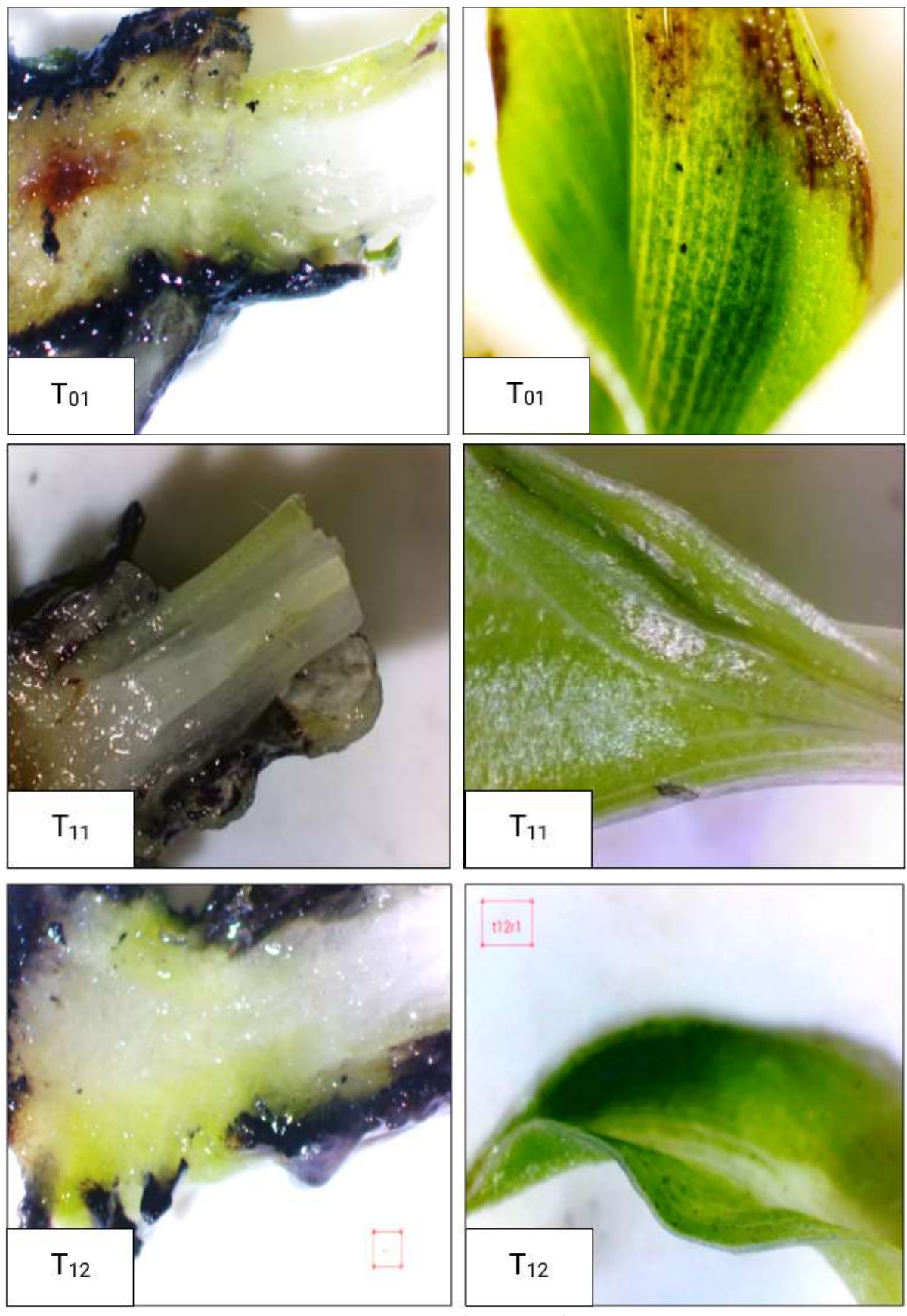

Figure 10. Dissected pseudostems and leaves of plantlets from untreated and treated explants 
In vitro growth response to bacterial wilt pathogen of banana

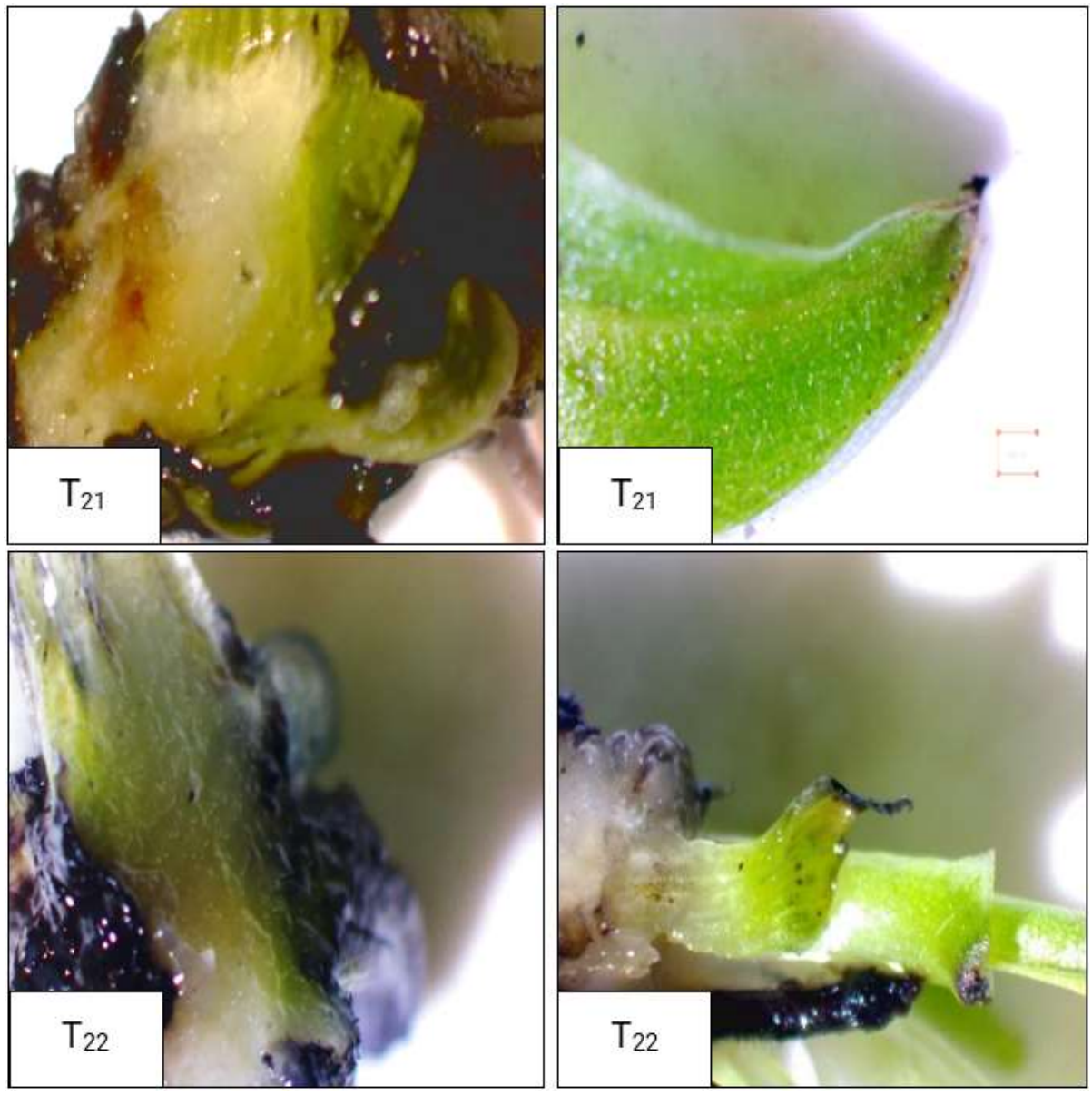

Figure 10 continued

\section{Percentages of Bacterial Wilt Infected and Clean Plantlets in Untreated and Treated Cultures}

All plantlets from untreated and $0.2 \%$ EMS treated explants exposed for $12 \mathrm{~h}$ had bacterial wilt infection (Figure 11). Plantlets from explants treated with $0.1 \%$ EMS for $24 \mathrm{~h}$ had $29 \%$ infection, while those regenerated from explants treated with $0.2 \%$ EMS for $24 \mathrm{~h}$ had $44 \%$ infection. All plantlets from explants exposed to $0.1 \%$ EMS for $12 \mathrm{~h}$ survived with no infection, suggesting that the plantlets might have improved ability to resist bacterial wilt infection. Uninfected surviving plantlets were also obtained from EMS-treated $\mathrm{T}_{12}(71 \%)$ and $\mathrm{T}_{22}(56 \%)$ explants. 


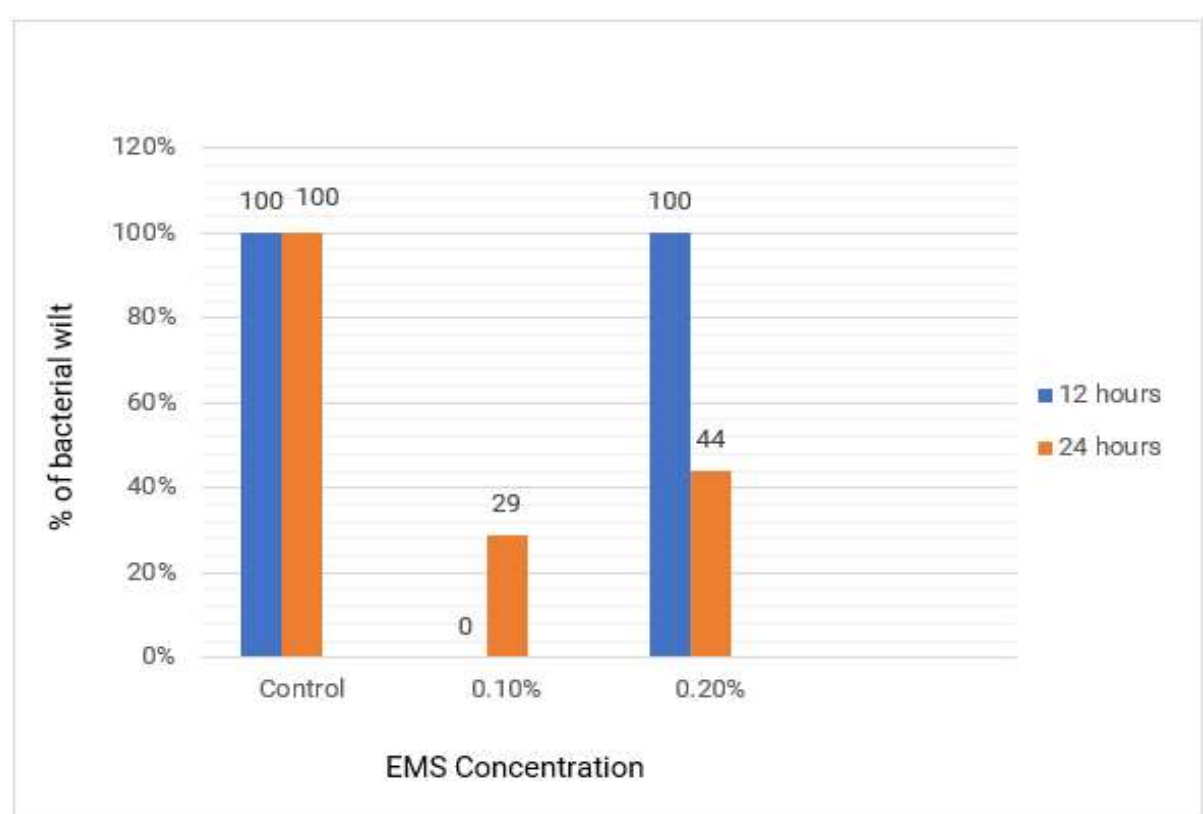

Figure 11. Percentage of bacterial wilt infected (susceptible) plantlets in untreated and EMS-treated cultures of Lakatan

EMS has the ability to enter the cells of living organisms and interact with the $D N A$, leading to changes in the genetic material, commonly with guanine $(G)$ at the 0 position, forming 0-6 ethylguanine, which can pair with thymine $(T)$ instead of cytosine (C), resulting in base pair errors (Greene et al 2007). This genetic change is known as "missense mutation" since different amino acids may be assembled during translation following base pair errors. The resulting protein could perform a different function giving the organism a changed trait. This possibility should be verified in the surviving plantlets.

\section{CONCLUSION AND RECOMMENDATION}

This study showed that shoot tip explants from Stage 2 in vitro-grown Lakatan plantlets can tolerate exposure to $0.1 \%$ and $0.2 \%$ EMS concentrations for 12 to $24 \mathrm{~h}$. These EMS levels and durations of exposure did not inhibit growth of shoots from the treated explants. Treatment with $0.1 \%$ EMS for $12 \mathrm{~h}$ apparently induced changes in the explants, which was manifested in this study as the absence of bacterial wilt symptoms up to ten days from the introduction of the pathogen during the early in vitro growth of $100 \%$ of the developing plantlets.

Mutation is a change in the genetic material. To confirm the presence of genetic changes in the surviving clean plantlets, ex vitro and molecular studies must be done. 
In vitro growth response to bacterial wilt pathogen of banana

\section{ACKNOWLEDGMENT}

The authors are grateful to Dr. Lucia M. Borines for allowing the use of the facilities in the Plant Disease Diagnostics Laboratory during the isolation and culture of the pathogen used in this study. They are also profoundly thankful to Ms. Victoria G. Palermo who expertly did the isolation and culture of the virulent Ralstonia solanacearum.

\section{REFERENCES}

Alvarez A, Gabriel DW, Allen C, Schell M, Denny TP, Zhukov A, Balogh B, Norman D, González ET, Presting G, Saddler G, Greenberg JT, Jones J, Clifford JM, Yao J, Swanson J, Elphinstone J, Castillo JA, Reddy J, Liu L, Patnaikuni M, Huang Q,Walunas T, Mulholland V, Farmerie W, Duan YP, Flores-Cruz Z \& Mikhailova N. 2006. Identification of open reading frames unique to a select agent: Ralstonia solanacearum race 3 biovar 2. Molecular Plant-Microbe Interactions 19(1):6979

Bhagwat B and Duncan EJ. 1988. Mutation breeding of banana cv. Highgate (Musa spp., AAA Group) for tolerance to Fusarium oxysporum f. sp. cubense using chemical mutagens. Scientia Horticulturae 73:11-22

Dadang L. 2014. Lakatan, The banana with many benefits and uses. Accessed August 2016 from https://lourdesdadang.wordpress.com/2014/10/29/ lakatan-the-banana-with-many-benefits-and-uses/

Dhakshanamoorthy D, Selvaraj R \& Chidambaram A. 2010. Physical and chemical mutagenesis in Jatropha curcas L. to induce variability in seed germination, growth and yield traits. Romanian Journal of Biology-Plant Biology 55: 113-125

Greene EA, Till BJ, Cooper J, Tai TH, Colowit P, Henikoff S \& Comai L. 2007. Discovery of chemically induced mutations in rice by Tilling. BMC Plant Biology 7:19

Jabeen N and Mirza B. 2004. Ethyl Methane Sulfonate induces morphological mutations in Capsicum annuum. International Journal of Agriculture and Biology 6(2):340-345

Khan S, Sahu J, Sahu RK \& Roy A. 2014. Micropropagation of dalbergia sisso robx. through tissue culture technique. Pakistan Journal of Biological Sciences 17(4):597-600

Konzak CF, Nilan RA, Wagner J \& Foster RJ. 1965. Efficient chemical mutagenesis in the use of induced mutations in plant breeding. Radiation Botany 5:49-70

Murashige T and Skoog F. 1962. A revised medium for rapid growth and bio assays with tobacco tissue cultures. Physiologia Plantarum 15(3):473-479

Omar MS, Novak FG \& Brunner H. 1989. In vitro action of ethyl methanesulphonate on banana shoot tips. Scientia Horticulturae 40:283-295

PSA (Philippine Statistic Authority). 2016.https://psa.gov.ph/sites/default/files /Fruits\%20Bulletin\%202016\%20Jan-Mar\%20Final\%2007012016.pdf Date Accessed: November 2016

Saraswathi MS, Uma S, Durai P \& Sathiamoorthy S. 2014. Diversity and distribution of section Rhodochlamys (genus Musa, Musaceae) in India and breeding potential for banana improvement programmes. Plant Genetic Newsletter 146: 17-23 